\title{
PEMBAGIAN TINGKAT KECANDUAN GAME ONLINE MENGGUNAKAN K-MEANS CLUSTERING SERTA KORELASINYA TERHADAP PRESTASI AKADEMIK
}

\author{
Yudi Prastyo, Puspa Eosina \& Fety Fatimah \\ Universitas Ibn Khaldun Bogor \\ e-mail: yudi.prastyo@studentpartner.com
}

\begin{abstract}
Online games not only provide entertainment but also provide interesting challenges to be solved so that individuals play online games without taking into account the time to achieve satisfaction. One method that can be used to group online addiction rates is the K-Means Clustering method. K-Means Clustering is one method of non-hierarchical data clustering that attempts to partition existing data into one or more clusters / groups. This research takes the data sample questionnaires from students at Ibn Khaldun University Bogor where the questionnaires will be processed as a reference grouping the online gameaddiction rate. Clustering results are used to determine the relationship between the online gameaddiction level to student achievement. $K$-Means Clustering has a variety of advantages including simple to understand, easy to implement, requires a little knowledge, able to handle numerical and categorical data, tough, and can handle large datasets. The resulting correlation value of -0.885 which means that the correlation between the level of online gameaddiction to student academic achievement at Ibn Khaldun University Bogor.
\end{abstract}

Keywords: Clustering, K-MEANS, academic achievement, online game, correlation

\begin{abstract}
ABSTRAK
Game online tidak hanya memberikan hiburan tetapi juga memberikan tantangan yang menarik untuk diselesaikan sehingga individu bermain game online tanpa memperhitungkan waktu demi mencapai kepuasan. Salah satu metode yang dapat digunakan untuk mengelompokkan tingkat kecanduan game online adalah metode K-Means Clustering. K-Means Clustering merupakan salah satu metode data clustering non hirarki yang berusaha mempartisi data yang ada ke dalam bentuk satu atau lebih cluster/kelompok.Penelitian ini mengambil data sample kuesioner dari mahasiswa di Universitas Ibn Khaldun Bogor dimana isian kuesioner akan diolah sebagai acuan pengelompokkan tingkat kecanduan game online.Hasil clusteringdigunakan untuk mengetahui hubungannya antara tingkat kecanduan game online terhadap prestasi akademik mahasiswa. K-Means Clustering memiliki berbagai keunggulan diantaranya sederhana untuk dipahami, mudah untuk diterapkan, membutuhkan sedikit pengetahuan, mampu menangani data numerik dan kategorikal, tangguh, dan dapat menangani dataset yang besar. Nilai korelasi yang dihasilkan sebesar -0,885yang berarti bahwa adanya korelasi antara tingkat kecanduan game online terhadap prestasi akademik mahasiswa di Universitas Ibn Khaldun Bogor.
\end{abstract}

Kata kunci: Clustering, K-MEANS, Prestasi Akademik, Game Online, Korelasi

\section{PENDAHULUAN}

Perkembangan teknologi berupa internetmemberikan manfaat yang sangat besar bagi kemajuan di segala bidang kehidupan. Hari ke hari internet menyuguhkan banyak penawaran yang menarik, alih-alih menggunakan internet untuk menyelesaikan tugas kuliah atau pekerjaan, kenyataannya banyak yang beralih pada game online (Pratiwi, Andayani \& Karyanta, 2012).

$$
\begin{array}{lccr}
\multicolumn{1}{c}{\text { Istilah }} & \text { kecanduan } & \text { (addiction) } & \text { awalnya } \\
\text { digunakan } & \text { terutama } & \text { mengacu kepada } \\
\text { penggunaan } & \text { alkohol dan obat-obatan. }
\end{array}
$$
Kecanduan adalah ketergantungan yang menetap dan kompulsif pada suatu perilakus atau zat. Kecanduan game online ditandai oleh sejauh mana seseorang bermain game secara berlebihan yang dapat berpengaruh negatif bagi pemain game tersebut (Weinsten, 2010).

Seseorang yang mengalami kecanduan game online akan mengalami beberapa gejala 
seperti salience (berpikir tentang bermain game online sepanjang hari), tolerance (waktu bermain game online yang semakin meningkat), mood modification (bermain game online untuk melarikan diri dari masalah), relapse (kecendrungan untuk bermain game online kembali setelah lama tidak bermain), withdrawal (merasa buruk jika tidak dapat bermain game online), conflict (bertengkar dengan orang lain karena bermain game online secara berlebihan), dan problems (mengabaikan kegiatan lainnya sehingga menyebabkan permasalahan). Tujuh kriteria kecanduan game online ini merupakan pengukuran untuk mengetahui kecanduan atau tidaknya seorang pemain game online yang ditetapkan pemain yang mendapatkan empat dari tujuh kriteria merupakan indikasi pemain yang mengalami kecanduan game online (Lemmens, Valkenburg \& Peter, 2009).

Banyak yang berasumsi kecanduan game online dapat menurunkan prestasi akademik bagi para mahasiswa, di perguruan tinggi keberhasilan belajar mahasiswa ditunjukkan dengan prestasi akademik yang dicapainya berdasarkan evaluasi hasil belajar (Pratiwi, Andayani \& Karyanta, 2012).

Salah satu metode yang dapat digunakan untuk mengetahui tingkat kecanduan came online adalah metode $K$-Means Clustering. $K$ Means Clustering merupakan salah satu metode data clustering non hirarki yang berusaha mempartisi data yang ada ke dalam bentuk satu atau lebih cluster/kelompok. Metode ini mempartisi data ke dalam cluster/kelompok sehingga data yang memiliki karakteristik sama dikelompokkan ke dalam satu cluster yang sama (Hastuti, 2013).

Penelitian ini mengambil data sample kuesioner dari mahasiswa di Universitas Ibn Khaldun Bogor dimana isian kuesioner akan diolah sebagai acuan pengelompokkan tingkat kecanduan game onlinedengan menggunakan metode K-Means Clustering, kemudian kelompok tersebut digunakan untuk mengetahui hubungannya antara tingkat kecanduan game online terhadap prestasi akademik mahasiswa. $K$-Means Clustering memiliki berbagai keunggulan diantaranya sederhana untuk dipahami, mudah untuk diterapkan, membutuhkan sedikit pengetahuan, mampu menangani data numerik dan kategorikal, tangguh, dan dapat menangani dataset yang besar.

\section{METODE}

Data mining adalah kegiatan menemukan pola yang menarik dari data dalam jumlah besar, data dapat disimpan dalam database, datawarehouse, atau penyimpanan informasi lainnya. Tahap-tahap data mining seperti tersaji pada Gambar 1 adalah sebagai berikut (Ridwan, Suryono, \& Sarosa, 2013): (1) pembersihan data (data cleaning) adalah pembersihan data merupakan proses menghilang-kan noise dan data yang tidak konsisten atau data tidak relevan; (2) integrasi data (data integration) adalah integrasi data merupakan penggabungan data dari berbagai database ke dalam satu database baru; (3) seleksi data (data selection) adalah data yang ada pada database sering kali tidak semuanya dipakai, oleh karena itu hanya data yang sesuai untuk dianalisis yang akan diambil dari database; (4) transformasi data (data transformation) adalah data diubah atau digabung ke dalam format yang sesuai untuk diproses dalam data mining; (5) proses mining adalah merupakan suatu proses utama saat metode diterapkan untuk menemukan pengetahuan berharga dan tersembunyi dari data; (6) evaluasi pola (pattern evaluation) adalah untuk mengidentifikasi pola-pola menarik ke dalam knowledgebased yang ditemukan; dan (7) presentasi pengetahuan (knowledge presentation) adalah merupakan visualisasi dan penyajian pengetahuan mengenai metode yang digunakan untuk memperoleh pengetahuan yang diperoleh pengguna. 


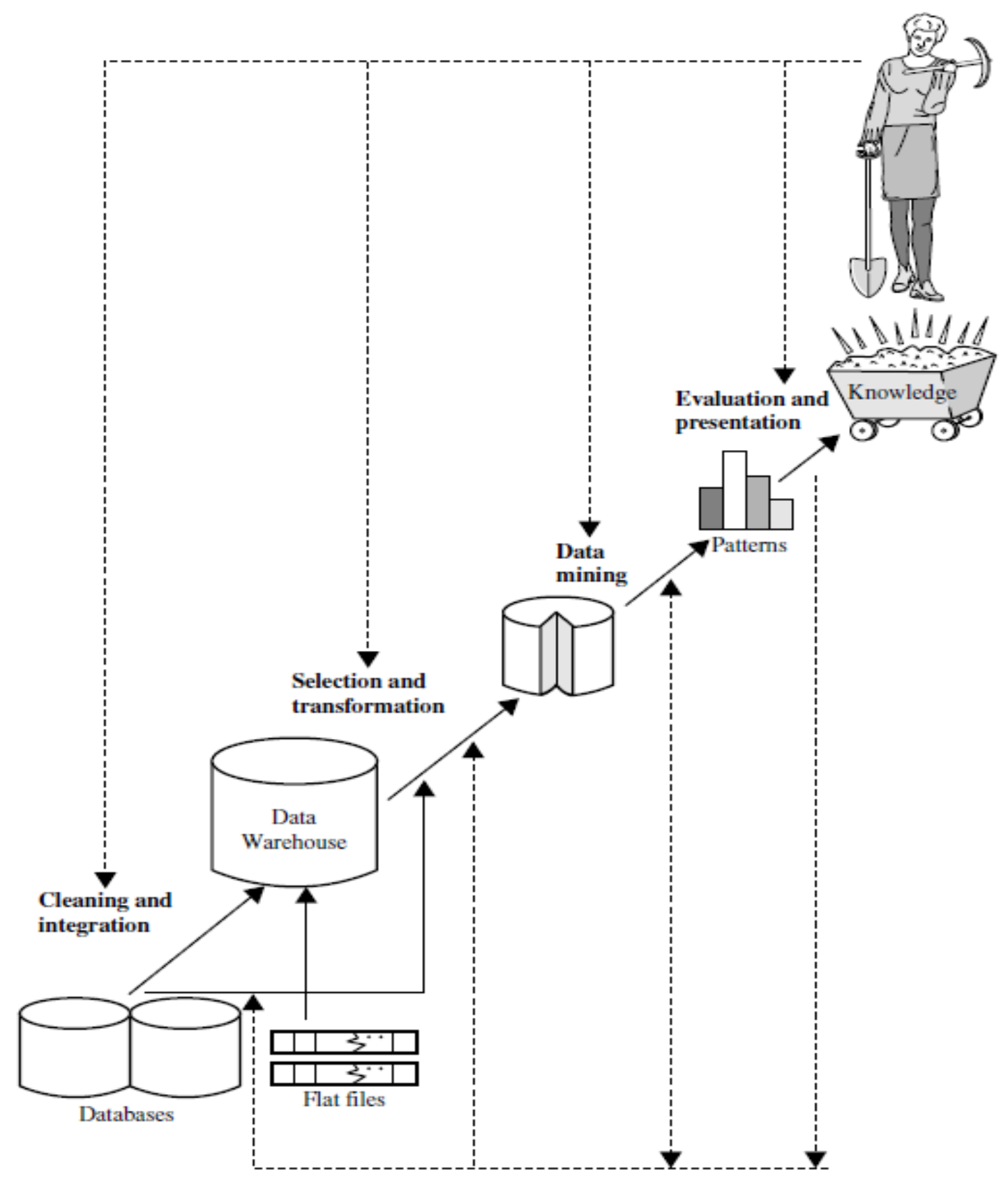

Gambar 1. Tahap Tahap Data mining

K-Means merupakan salah satu metode clustering yang sering sekali digunakan. Pertama-tama kita memilih K (merupakan initial dari centroid). Untuk menentukan centroid dapat kita mengambil poin secara random. Setiap poin yang berada pada sekitar centroid akan membentuk sebuah kumpulan baru yang dinamakan klaster, Lakukan hal tersebut berulang kali sampai tidak terdapat perubahan pada point klaster ataupun pada centroid (Nugroho, Hendrawan \& Hafidz, 2012). Ilustrasi dari perubahan klaster/ kelompok data ditunjukkan pada Gambar 2. 


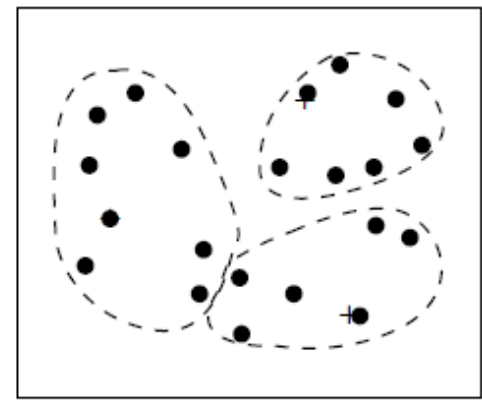

(a) Initial clustering

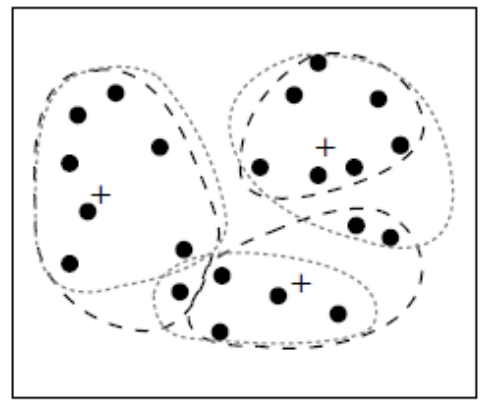

(b) Iterate

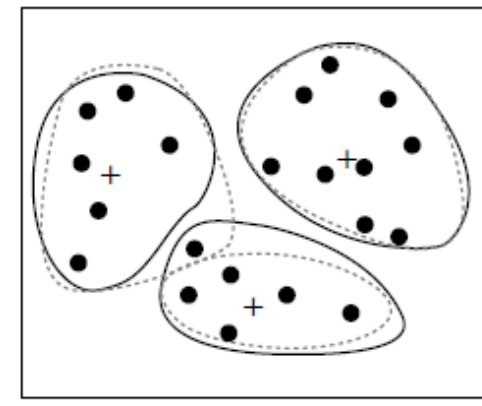

(c) Final clustering

Gambar 2.K-Means Clustering

Secara umum, algoritma pengelompokan digunakan untuk mengelompokkan beberapa objek tertentu yang didefinisikan oleh serangkaian properti numerik sedemikian rupa sehingga objek dalam kelompok lebih mirip daripada objek dalam kelompok yang berbeda. Oleh karena itu, algoritma clustering tertentu perlu disediakan, kriteria untuk mengukur kesamaan objek, bagaimana mengelompokkan objek atau titik ke dalam cluster (Singh, Yadav \& Rana, 2013).

Diagram pada Gambar 3 adalah Alur/Flow dari Algoritma K-Means Clustering (Kristanto, 2016). Penjelasan Alur/Flow dari Algoritma K-Means Clustering dari Gambar 3, yaitu: (1) memilih 'c' pusat cluster secara acak; (2) hitung jarak antara setiap titik data dan ke pusat cluster menggunakan perhitungan jarak Euclidean sebagai berikut:

$$
d\left(x_{i}, \mu_{j}\right)=\sqrt{\left(x_{i a}-\mu_{j a}\right)^{2}+\left(x_{i n}-\mu_{j n}\right)^{2}} .
$$

Dimana :

$x_{i}$ : Data kuesioner

$\mu_{j}:$ Centroid pada cluster ke-j

$x_{i a}:$ Feature atribut

$\mu_{j a}$ : Nilai kriteria 1 dari centroidcluster

ke-jyang berupa nilai random dari feature atribut $x_{i a}$

(3) menentukan titik data ke pusat cluster yang jaraknya dari pusat cluster paling dekat dari semua pusat cluster; (4) pusat cluster baru dihitung dengan menggunakan:

$$
V_{i}=\left(\frac{1}{C i}\right) \sum_{1}^{C i} x_{i}
$$

Dimana, ' $C i$ ' menunjukkan jumlah titik data di cluster tersebut.

(5) jarak antara setiap titik data dan pusat cluster yang baru diperoleh dihitung ulang; dan (6) jika tidak ada titik data yang ditugaskan kembali maka berhentilah, jika tidak, ulangi langkah 3 sampai 5.

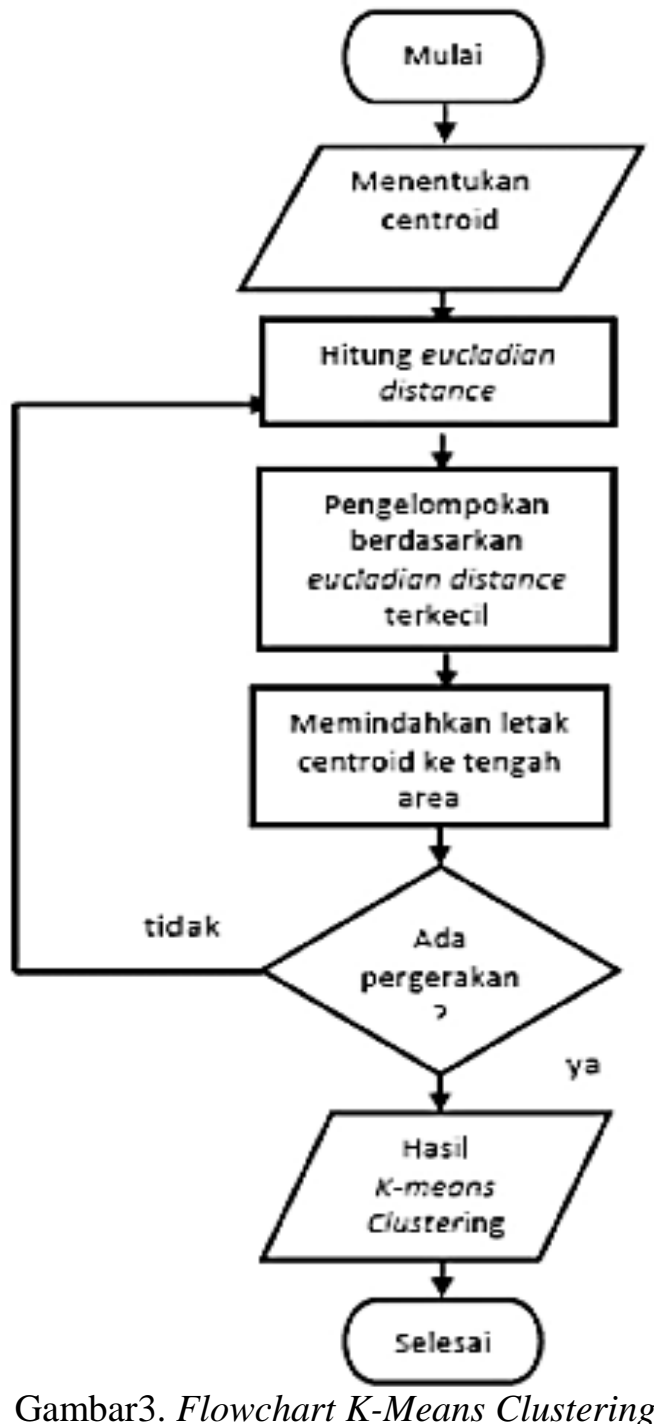


Kekuatan K-Means Clustering adalah karena efisiensi komputasi dan sifat kemudahan penggunaannya. Langkah penting dalam clustering adalah memilih algoritma perhitungan Distance (jarak), salah satu algoritmanya yang digunakan adalah Euclidean Distance. Euclidean Distance adalah algoritma untuk mengukur kemiripan/jarak antar objek. Menurut Singh, K-means Clustering yang diimplementasikan dengan menggunakan algoritma perhitungan Euclidean Distance memberikan hasil terbaik dibandingkan dengan algoritma lainnya (Singh, Yadav \& Rana, 2013).

Correlation atau korelasi adalah suatu nilai yang menunjukkan keeratan hubungan antara dua variabel. Dua variabel disebut berkorelasi positif bila kedua buah variabel tersebut mengalami kenaikan yang serupa, seperti diperlihatkan pada Gambar 4.

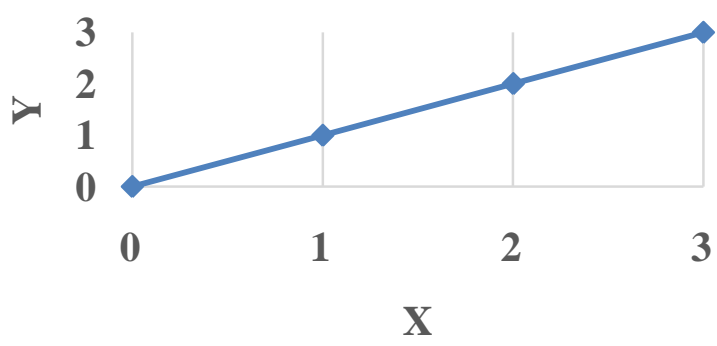

Gambar 4.Correlation Positif

Dua variabel disebut berkorelasi negatif bila kedua buah variabel berlawanan (satu variabel mengalami kenaikan ketika variabel lainnya mengalami penurunan nilai). Hal tersebut dapat dilihat pada Gambar 5.

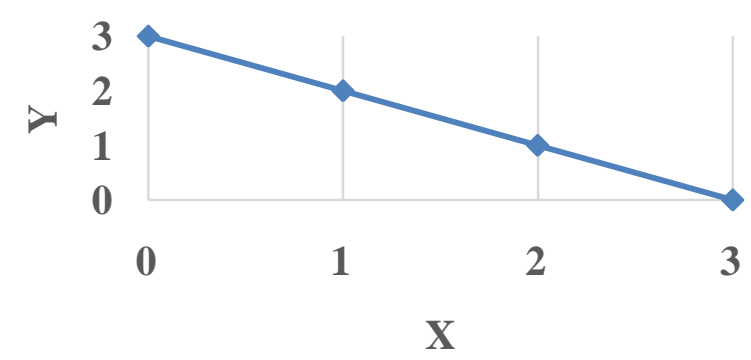

Gambar 5. Correlation Negatif
Dua variabel disebut tidak berkorelasi bila Kedua variabel tidak tidakberelasi linear satusama lain. Hal tersebut dapat dilihat pada Gambar 6.

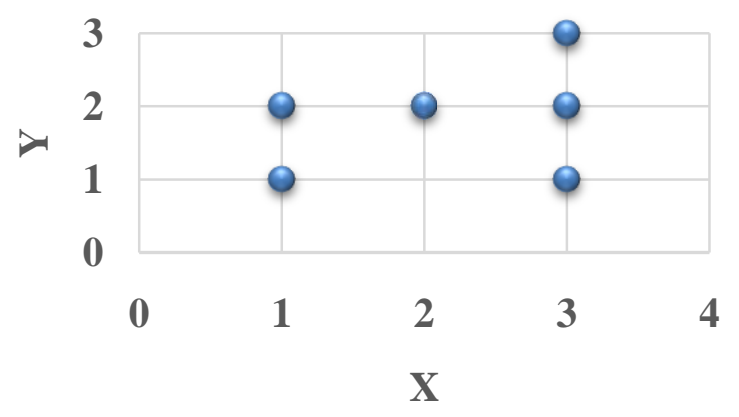

Gambar 6.Tidak Berkorelasi

Formula untuk menghitung korelasi pada data sampel adalah :

$$
\operatorname{kor}(x, y)=r_{x y}=\frac{\sum_{i=1}^{n}\left(x_{i}-\bar{x}\right)\left(y_{i}-\bar{y}\right)}{\sqrt{\sum_{i=1}^{n}\left(x_{i}-\bar{x}\right)^{2} \sum_{i=1}^{n}\left(y_{i}-\bar{y}\right)^{2}}} \ldots
$$

Sedangkan untuk data populasi adalah :

$$
\operatorname{kor}(x, y)=\rho_{x y}=\frac{\operatorname{cov}(x, y)}{\sigma_{x} \sigma_{y}} \ldots \ldots
$$

Dimana

$\sum \quad$ : untukmenghitungpenjumlahan $\left(x_{i}-\bar{x}\right):$ nilai $x_{i}$ dikurangi rata-ratanya, $\bar{x}$ $\left(y_{i}-\bar{y}\right)$ : nilai $x_{i}$ dikurangi rata-ratanya, $\bar{x}$ $\operatorname{cov}(x, y)$ : Correlationdari $\mathrm{x}$ dan $\mathrm{y}$ $\sigma_{x} \sigma_{y} \quad$ : standar deviasi dari $\mathrm{x}$ dan $\mathrm{y}$

\section{HASIL}

Tabel 1, Tabel 2 dan Tabel 3 menunjukkan jumlah data yang diambil dari 6 Fakultas yang ada di Universitas Ibn Khaldun Bogor meliputi mahasiswa dan mahasiswi aktif mulai dari angkatan 2017 sampai dengan angkatan 2010.

Tabel 1. Jumlah data menurut jenis kelamin

\begin{tabular}{ll}
\hline Jenis Kelamin & Jumlah data \\
\hline Laki-laki & 61 data \\
Perempuan & 9 data \\
Total & 70 data \\
\hline
\end{tabular}


Tabel 2. Jumlah data menurut fakultas

\begin{tabular}{ll}
\hline \multicolumn{1}{c}{ Nama Fakultas } & Jumlah data \\
\hline Fakultas Keguruan dan Ilmu & 6 data \\
Pendidikan & 17 data \\
Fakultas Hukum & 18 data \\
Fakultas Ekonomi & 5 data \\
Fakultas Agama Islam & 23 data \\
Fakultas Teknik & 1 data \\
Fakultas Ilmu Kesehatan & 70 data \\
Total & \\
\hline
\end{tabular}

Tabel 3. Jumlah data menurut fakultas

\begin{tabular}{ll}
\hline Angkatan & Jumlah data \\
\hline 2017 & 1 data \\
2016 & 6 data \\
2015 & 14 data \\
2014 & 25 data \\
2013 & 19 data \\
2012 & 1 data \\
2011 & 1 data \\
2010 & 1 data \\
NA & 2 data \\
Total & 70 data \\
\hline
\end{tabular}

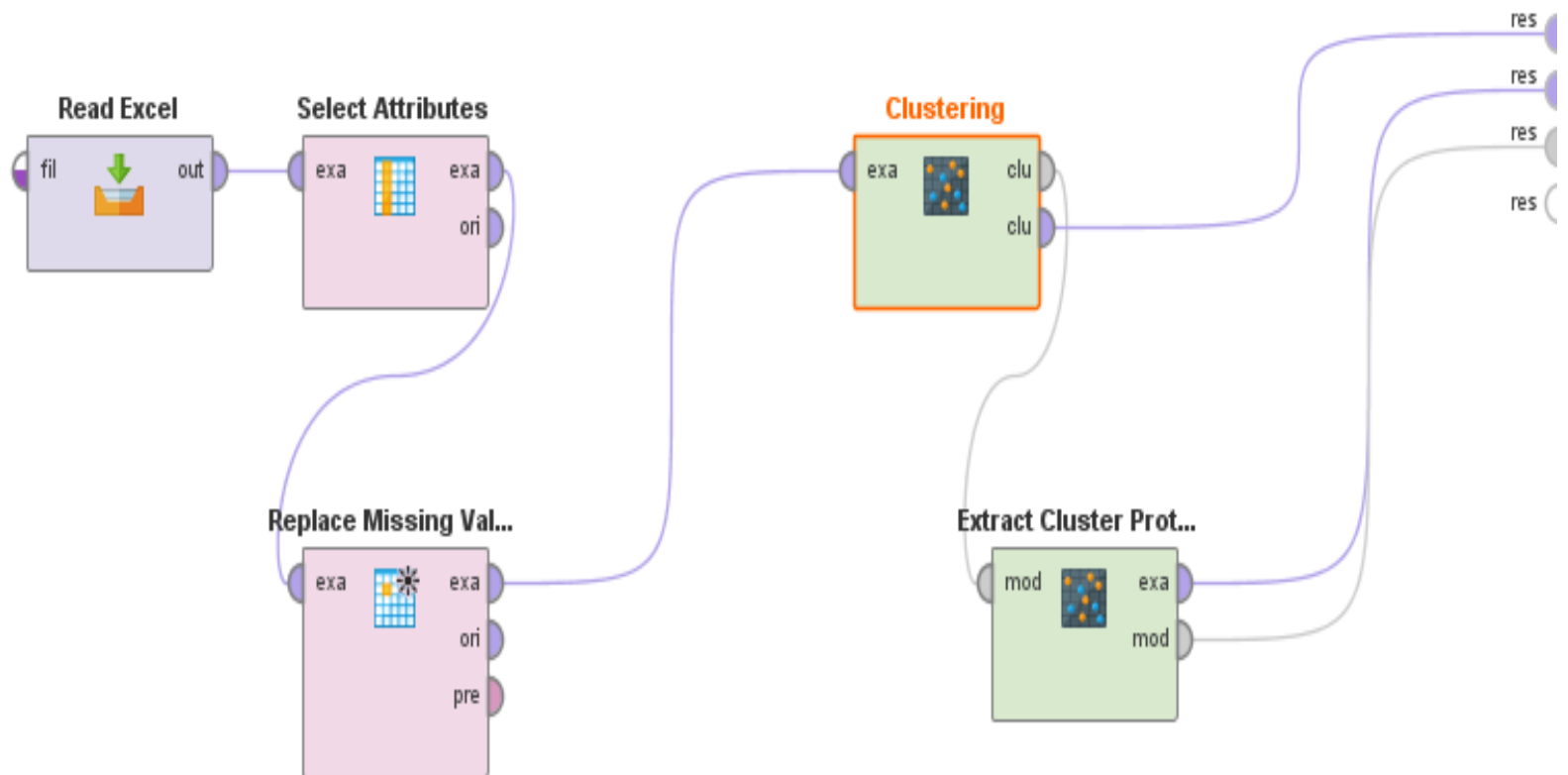

Gambar 7. Proses K-Means Clustering menggunakan software Rapid Miner Studio

Proses clustering dengan menggunakan metode $K$-Means akan dilakukan terhadap 70 sampel data kuesioner mahasiswa. Pengolahan data kuesionernya menggunakan bantuan
Dibagian data skala kecanduan game online (bagian $\mathrm{B}$ pada kuesioner) diberi inisialisasi dari bentuk kategorikal (Tidak Pernah, Jarang, Sering dan Selalu) menjadi sebuah angka dari 1 (satu) sampai dengan 4 (empat) dan untuk data yang tidak lengkap/kosong, akan di isi dengan angka 0 (nol). Jika pertanyaan negatif inisialisasi angkanya akan dibalik. Hal tersebut tersaji pada Tabel 4.

Tabel 4. Inisialisasi jawaban skala kecanduan

\begin{tabular}{lll}
\multicolumn{3}{c}{ game online } \\
Jawaban & $\begin{array}{l}\text { Inisialisasi } \\
\text { angka } \\
\text { (pertanyaan } \\
\text { positif) }\end{array}$ & $\begin{array}{l}\text { Inisialisasi } \\
\text { angka } \\
\text { (pertanyaan } \\
\text { negatif) }\end{array}$ \\
\hline Selalu & 4 & 1 \\
Sering & 3 & 2 \\
Jarang & 2 & 3 \\
Tidak Pernah & 1 & 4 \\
Kosong & 0 & 0 \\
\hline
\end{tabular}

Dari inisialisasi angka tersebut maka total skala yang akan dihasilkan oleh setiap data akan berada dalam kisaran 0 sampai dengan 92 . 
Sebelum masuk ke proses K-Means Clustering, terlebih dahulu melalui proses Feature Selection (select Attributes) sesuai keterkaitan terhadap kecanduan game online dan Mengisi nilai kosong dengan menggunakan Replace Missing Value. K-Means Clustering ini Perhitungan rumus jarak Eucledian dengan maksimal iterasi 10 kali yang berjalan dengan inisialisasi secara acak dan maksimal 100 kali iterasi yang dilakukan dalam satu putaran. Ditentukan banyaknya cluster adalah sebanyak 4 cluster.

Berdasarkan hasil perhitungan jarak dengan menggunakan rumus jarak Eucledian, maka setiap data akan menjadi anggota suatu cluster yang memiliki jarak terdekat dari hasil nilai terkecil dari centroid-nya seperti tersaji pada Tabel 5.

Tabel 5.Centroid akhir tiap atribut

\begin{tabular}{lllll}
\hline $\begin{array}{l}\text { Feature } \\
\text { Attribute }\end{array}$ & $\begin{array}{l}\text { Cen- } \\
\text { troid 0 }\end{array}$ & $\begin{array}{l}\text { Cen- } \\
\text { troid 1 }\end{array}$ & $\begin{array}{l}\text { Cen- } \\
\text { troid 2 }\end{array}$ & $\begin{array}{l}\text { Cen- } \\
\text { troid 3 }\end{array}$ \\
\hline $\begin{array}{l}\text { Durasi } \\
\text { Bermain }\end{array}$ & 4.05 & 1.75 & 7.25 & 1.47 \\
Game & & & & \\
Q1 & 2.33 & 2.60 & 3.00 & 2.29 \\
Q2 & 1.95 & 1.65 & 2.58 & 1.76 \\
Q3 & 2.67 & 1.70 & 2.50 & 1.88 \\
Q4 & 2.00 & 2.00 & 2.58 & 1.00 \\
Q5 & 2.67 & 2.45 & 3.42 & 2.18 \\
Q6 & 2.29 & 2.60 & 3.00 & 1.88 \\
Q8 & 1.90 & 1.90 & 2.42 & 1.65 \\
Q9 & 2.57 & 2.15 & 3.08 & 1.94 \\
Q10 & 2.38 & 2.70 & 3.17 & 1.35 \\
Q11 & 2.14 & 1.75 & 2.33 & 1.47 \\
Q13 & 2.67 & 2.20 & 2.50 & 2.06 \\
Q14 & 2.38 & 2.15 & 3.17 & 1.82 \\
Q15 & 2.19 & 1.60 & 2.50 & 1.65 \\
Q17 & 1.90 & 2.30 & 2.50 & 1.06 \\
Q18 & 2.38 & 2.85 & 2.92 & 1.76 \\
Q20 & 2.57 & 3.20 & 3.33 & 2.35 \\
Q22 & 1.71 & 1.70 & 2.33 & 1.76 \\
Q23 & 2.29 & 2.20 & 3.17 & 1.88 \\
\hline
\end{tabular}

Misalkan untuk data pertama diperoleh hasil jarak terdekat dengan centroid 2, maka data tersebut akan masuk menjadi anggota cluster 2. Lalu semua data yang telah dihitung akan dimasukkan kedalam anggota cluster. Dari hasil cluster didapatkan jumlah data pada setiap cluster yang dijelaskan pada Tabel 6.

Tabel 6. Jumlah data tiap cluster

\begin{tabular}{ll}
\hline Cluster & Jumlah \\
\hline Cluster 0 & 21 data \\
Cluster 1 & 20 data \\
Cluster 2 & 12 data \\
Cluster 3 & 17 data \\
Total & 70 data \\
\hline
\end{tabular}

Mengacu pada hasil clustering yang diperoleh maka perlu adanya suatu aturan untuk menentukan kelompok (cluster) mana yang memiliki tingkat kecanduan game online yang tinggi. Dalam penelitian ini, tingkat kecanduan game online dibagi menjadi 4 kelompok (cluster) yaitu: (1) Cluster yang tingkat kecanduan parah; (2) Cluster yang tingkat kecanduan sedang; (3) Cluster yang tingkat waspada kecanduan game online; dan (4) Cluster yang tidak kecanduan game online.

Dari pembagian cluster diatas didapatkan kecocokan terhadap cluster yang telah terbentuk dari hasil clustering. Dengan menghitung nilai rata-rata setiap atribut yang terdapat pada setiap cluster maka dapat ditentukan kelompok cluster mana yang memiliki tingkat kecanduan game online parah hingga yang tidak kecanduan game online. Tabel 7 merupakan klasifikasi hasil clustering.

Tabel 7. Klasifikasi hasil clustering

\begin{tabular}{llcc}
\hline Cluster & \multicolumn{1}{c}{ Keterangan } & $\begin{array}{c}\text { Rata-rata } \\
\text { keseluruhan }\end{array}$ & $\begin{array}{c}\text { Tingkat } \\
\text { kecanduan }\end{array}$ \\
\hline Cluster 2 & Cluster yang tingkat kecanduan parah & 3.04 & 4 \\
Cluster 0 & Cluster yang tingkat kecanduan sedang & 2.37 & 3 \\
Cluster 1 & Cluster yang tingkat waspada kecanduan game online & 2.18 & 2 \\
Cluster 3 & Cluster yang tidak kecanduan game online & 1.75 & 1 \\
\hline
\end{tabular}


Cluster 2 atau yang sudah ditentukan sebagai "cluster yang selalu kecanduan game online" memiliki durasi bermain game online paling lama. Data kuesioner mahasiswa yang termasuk dalam cluster 2 ini menghabiskan waktu untuk bermain game online diatas dari lima jam perharinya. Sedangkan cluster 0 atau "cluster yang sering kecanduan game online" menghabiskan waktu untuk bermain game online selama 2,5 jam sampai 5,5 jam lalu untuk cluster 1 atau "cluster yang jarang kecanduan game online" dan cluster 3 atau "cluster yang tidak kecanduan game online" menghabiskan waktu untuk bermain game online selama kurang dari 4 jam sehari. Hal tersebut tersaji pada Gambar 8 .

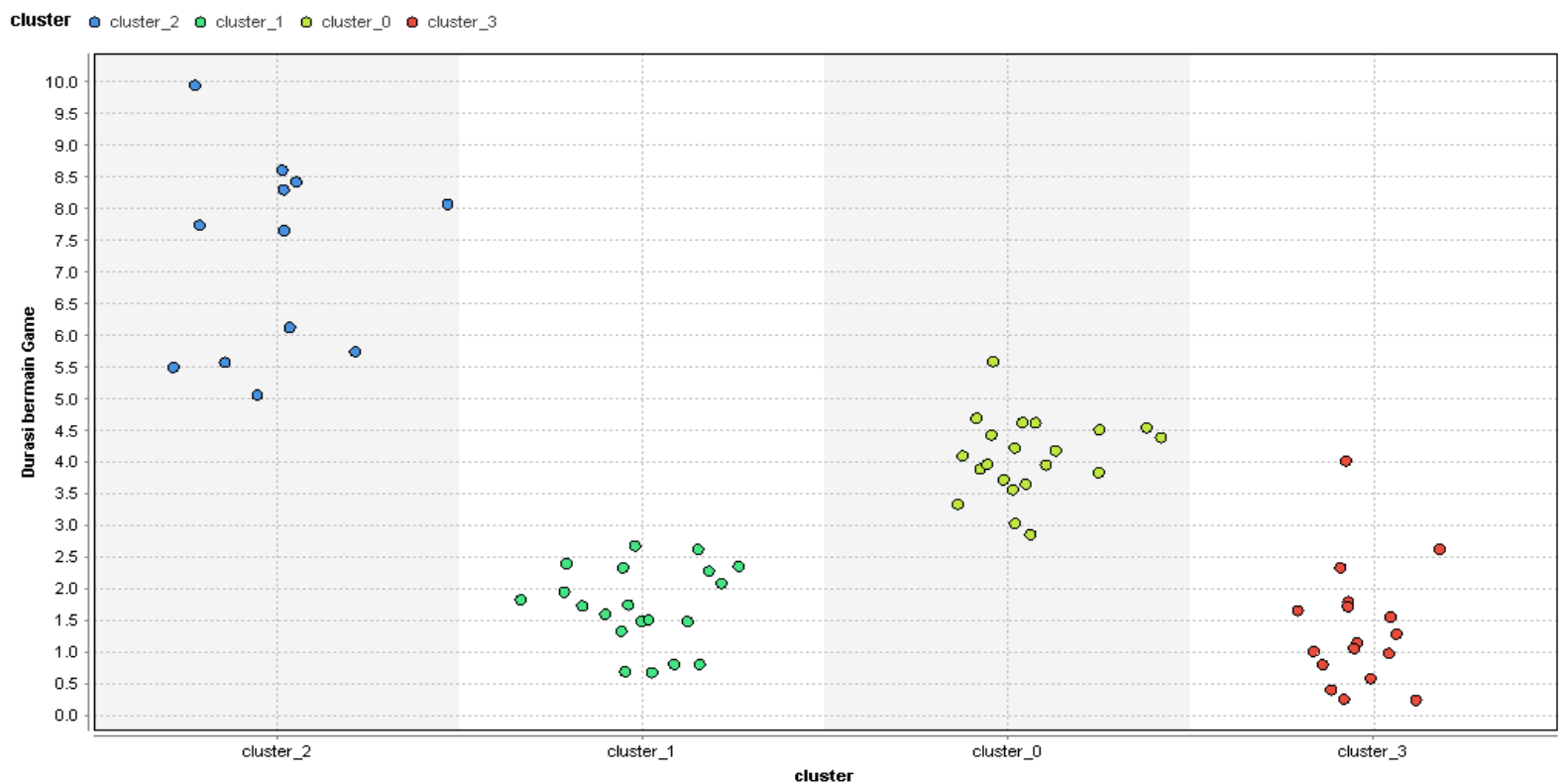

Gambar 8. Grafik durasi game online terhadap cluster

Rincian rata-rata kecanduan game online dapat dilihat pada Tabel 8 .

Tabel 8. Rata-rata kecanduan game online tiap

\begin{tabular}{lc}
\multicolumn{1}{c}{ cluster } \\
\hline \multicolumn{1}{c}{ Cluster } & $\begin{array}{c}\text { Rata-rata } \\
\text { kecanduan game } \\
\text { online }\end{array}$ \\
$\begin{array}{l}\text { Cluster 2 (Cluster yang } \\
\text { tingkat kecanduan } \\
\text { parah) }\end{array}$ & 2.81 \\
$\begin{array}{l}\text { Cluster 0 (Cluster yang } \\
\text { tingkat kecanduan }\end{array}$ & 2.28 \\
sedang) \\
$\begin{array}{l}\text { Cluster 1 (Cluster yang } \\
\text { tingkat waspada } \\
\text { kecanduan game online) } \\
\begin{array}{l}\text { Cluster 3 (Cluster yang } \\
\text { tidak kecanduan game } \\
\text { online) }\end{array}\end{array}$ \\
\hline
\end{tabular}

Hasil dari clustering dikorelasikan dengan Indeks Prestasi Kumulatif (IPK) tiap data mahasiswa dengan menggunakan Correlation matrix. Hasil dari Correlation matrix dengan bantuan software Rapid Miner Studio seperti ditunjukkan pada Gambar 9.

\begin{tabular}{|l|l|l|}
\hline Attribut... & IPK (A) & Tingkat ... \\
\hline IPK (A) & 1 & -0.885 \\
\hline Tingkat ... & -0.885 & 1 \\
\hline
\end{tabular}

Gambar 9. Hasil Correlation Matrix

Hasil menunjukkan bahwa IPK dan tingkat kecanduan game online (cluster) berkorelasi negatif karena kedua variabel mengalami perubahan pada arah berlawanan, ketika variabel kecanduan game online berada pada nilai tinggi, variabel IPK berada pada nilai rendah. Dengan nilai sebesar -0.885 . Grafik korelasi IPK terhadap tingkat kecanduan dapat dilihat pada Gambar 10. 


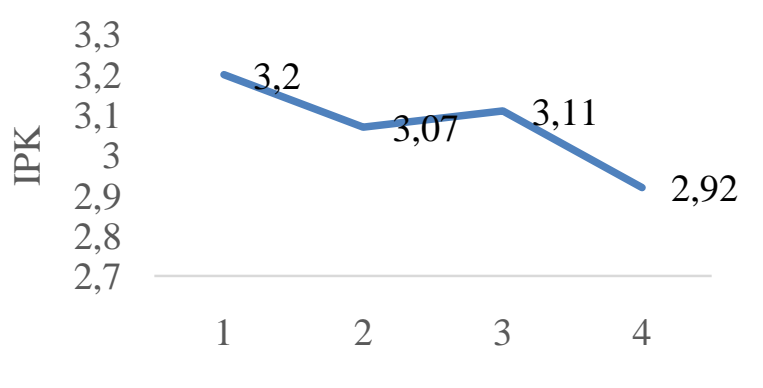

Tingkat Kecanduan

Gambar 10. Korelasi antara cluster terhadap rata-rata IPK
Salah satu faktor yang mempengaruhi tingkat kecanduan game online mahasiswa Universitas Ibn Khaldun Bogor adalah Relapse. Relapse merupakan kecenderungan untuk bermain game online kembali setelah lama tidak bermain. Nilai rata-rata Relapse secara keseluruhan sebesar 2,54 dan nilai tertinggi di Cluster 2 adalah 3,33 (Jarang) di pertanyaan "Saya bertekad untuk berhenti bermain game online." Hal tersebut tersaji pada Tabel 9.

Tabel 9. Detil hasil faktor Relapse

\begin{tabular}{|c|c|c|c|c|c|}
\hline No & Pertanyaan & Cluster 0 & Cluster 1 & Cluster 2 & Cluster 3 \\
\hline Q1+ & $\begin{array}{l}\text { Saya berharap dapat segera bermain game } \\
\text { online lagi pada saat sedang offline. }\end{array}$ & $\begin{array}{l}2.33 \\
\text { (Jarang) }\end{array}$ & $\begin{array}{l}2.6 \\
\text { (Sering) }\end{array}$ & $\begin{array}{l}3.00 \\
\text { (Sering) }\end{array}$ & $\begin{array}{l}2.29 \\
\text { (Jarang) }\end{array}$ \\
\hline Q13 & $\begin{array}{l}\text { Saya lebih memilih untuk pergi dengan } \\
\text { teman-teman saya dibandingkan dengan } \\
\text { bermain game online. }\end{array}$ & $\begin{array}{l}2.67 \\
\text { (Jarang) }\end{array}$ & $\begin{array}{l}2.2 \\
\text { (Sering) }\end{array}$ & $\begin{array}{l}2.50 \\
\text { (Jarang) }\end{array}$ & $\begin{array}{l}2.06 \\
\text { (Sering) }\end{array}$ \\
\hline $\begin{array}{l}\text { Q20 } \\
-\end{array}$ & $\begin{array}{l}\text { Saya bertekad untuk berhenti bermain } \\
\text { game online. }\end{array}$ & $\begin{array}{l}2.57 \\
\text { (Jarang) }\end{array}$ & $\begin{array}{l}3.2 \\
\text { (Jarang) }\end{array}$ & $\begin{array}{l}3.33 \\
(\text { Jarang) }\end{array}$ & $\begin{array}{l}2.35 \\
\text { (Sering) }\end{array}$ \\
\hline $\begin{array}{l}\text { Q23 } \\
+\end{array}$ & $\begin{array}{l}\text { Saya merasa lebih nyaman pada saat } \\
\text { sedang bermain game online daripada } \\
\text { pada saat sedang melakukan hal yang lain. }\end{array}$ & $\begin{array}{l}2.29 \\
\text { (Jarang) }\end{array}$ & $\begin{array}{l}2.2 \\
\text { (Jarang) }\end{array}$ & $\begin{array}{l}3.17 \\
\text { (Sering) }\end{array}$ & $\begin{array}{l}1.88 \\
\text { (Jarang) }\end{array}$ \\
\hline
\end{tabular}

Faktor lainnya yang mempengaruhi tingkat kecanduan game online mahasiswa Universitas Ibn Khaldun Bogor adalah Mood Modification. Mood Modification merupakan bermain game online untuk melarikan diri dari masalah. Nilai rata-rata Mood Modification secara keseluruhan sebesar 2,44 dan nilai tertinggi di Cluster 2 adalah 3 (Sering) di pertanyaan "Saya merubah pikiran-pikiran yang mengganggu mengenai hidup saya dengan pikiran-pikiran yang menyenangkan saat bermain game online." Hal tersebut tersaji pada Tabel 10.

Tabel 10. Detil hasil faktor Mood Modification

\begin{tabular}{lllllll}
\hline No & Pertanyaan & Cluster 0 & Cluster 1 & Cluster 2 & Cluster 3 \\
\hline Q6 & Saya merubah pikiran-pikiran yang & 2.29 & 2.6 & 3.00 & 1.88 \\
+ & $\begin{array}{l}\text { mengganggu mengenai hidup saya dengan } \\
\text { pikiran-pikiran yang menyenangkan saat } \\
\text { bermain game online. }\end{array}$ & & & & & \\
& & & & & \\
\end{tabular}

Faktor keriga yang mempengaruhi tingkat kecanduan game online mahasiswa Universitas Ibn Khaldun Bogor adalah Conflict. Conflict merupakan bertengkar dengan orang lain karena bermain game online secara berlebihan. Perolehan nilai rerata untuk faktor tersebut secara keseluruhan sebesar 2,43 dan nilai tertinggi di Cluster 2 adalah 3,42 (Sering) di pertanyaan "Saya menjadi kesal jika seseorang mengganggu saya pada saat sedang bermain game online". Hal tersebut tersaji pada Tabel 11. 
Tabel 11. Detil hasil faktor Conflict

\begin{tabular}{|c|c|c|c|c|c|}
\hline No & Pertanyaan & Cluster 0 & Cluster 1 & Cluster 2 & Cluster 3 \\
\hline Q3+ & $\begin{array}{l}\text { Pada saat sedang bermain game online, } \\
\text { saya merasa terganggu jika ditanya oleh } \\
\text { orangtua/ anggota keluarga saya } \\
\text { mengenai apa yang saya lakukan. }\end{array}$ & $\begin{array}{l}2.67 \\
\text { (Sering) }\end{array}$ & $\begin{array}{l}1.7 \\
\text { (Jarang) }\end{array}$ & $\begin{array}{l}2.50 \\
\text { (Sering) }\end{array}$ & $\begin{array}{l}1.88 \\
\text { (Jarang) }\end{array}$ \\
\hline Q5+ & $\begin{array}{l}\text { Saya menjadi kesal jika seseorang } \\
\text { mengganggu saya pada saat sedang } \\
\text { bermain game online. }\end{array}$ & $\begin{array}{l}2.67 \\
\text { (Sering) }\end{array}$ & $\begin{array}{l}2.45 \\
\text { (Sering) }\end{array}$ & $\begin{array}{l}3.42 \\
\text { (Sering) }\end{array}$ & $\begin{array}{l}2.18 \\
\text { (Jarang) }\end{array}$ \\
\hline Q7+ & $\begin{array}{l}\text { Teman-teman saya mengeluhkan } \\
\text { kegiatan bermain game onlineyang saya } \\
\text { lakukan. }\end{array}$ & & \multicolumn{3}{|c|}{ Feature tidak digunakan } \\
\hline $\begin{array}{l}\text { Q12 } \\
+\end{array}$ & $\begin{array}{l}\text { Saya bermain game online secara } \\
\text { bersembunyi-sembunyi dari orangtua. }\end{array}$ & & \multicolumn{3}{|c|}{ Feature tidak digunakan } \\
\hline $\begin{array}{l}\text { Q16 } \\
+\end{array}$ & $\begin{array}{l}\text { Saya menutup-nutupi jumlah waktu } \\
\text { yang saya gunakan untuk bermain game } \\
\text { online. }\end{array}$ & & \multicolumn{3}{|c|}{ Feature tidak digunakan } \\
\hline $\begin{array}{l}\text { Q19 } \\
+\end{array}$ & $\begin{array}{l}\text { Orang-orang terdekat saya mengeluhkan } \\
\text { jumlah waktu yang saya gunakan untuk } \\
\text { bermain game online. }\end{array}$ & & \multicolumn{3}{|c|}{ Feature tidak digunakan } \\
\hline
\end{tabular}

Faktor keriga yang mempengaruhi tingkat kecanduan game online mahasiswa Universitas Ibn Khaldun Bogor adalah Tolerance. Tolerance yang dimaksud adalah waktu bermain game online yang semakin meningkat dengan nilai rata-rata keseluruhan sebesar 2,42 dan nilai tertinggi di Cluster 2 adalah 3,17 (Jarang) di pertanyaan "Saya membatasi waktu dalam bermain game online." dan di pertanyaan "Saya bermain game online lebih lama dari yang telah direncanakan." Hal tersebut tersaji pada Tabel 12 .

Tabel 12. Detil hasil faktor Tolerance

\begin{tabular}{|c|c|c|c|c|c|}
\hline No & Pertanyaan & Cluster 0 & Cluster 1 & Cluster 2 & Cluster 3 \\
\hline Q10- & $\begin{array}{l}\text { Saya } \\
\text { membatasiwaktudalambermainga } \\
\text { me online. }\end{array}$ & $\begin{array}{l}2.38 \\
\text { (Sering) }\end{array}$ & $\begin{array}{l}2.7 \\
\text { (Jarang) }\end{array}$ & $\begin{array}{l}3.17 \\
\text { (Jarang) }\end{array}$ & $\begin{array}{l}1.35 \\
\text { (Selalu) }\end{array}$ \\
\hline Q14+ & $\begin{array}{l}\text { Saya bermaingame onlinelebih } \\
\text { lama dari yang telahdirencanakan. }\end{array}$ & $\begin{array}{l}2.38 \\
\text { (Jarang) }\end{array}$ & $\begin{array}{l}2.15 \\
\text { (Jarang) }\end{array}$ & $\begin{array}{l}3.17 \\
\text { (Sering) }\end{array}$ & $\begin{array}{l}1.82 \\
\text { (Jarang) }\end{array}$ \\
\hline Q18+ & $\begin{array}{l}\text { Saya berkatadidalamhati, } \\
\text { "Hanyabeberapamenitlagi" } \\
\text { padasaatsedangbermaingame } \\
\text { online. }\end{array}$ & $\begin{array}{l}2.38 \\
\text { (Jarang) }\end{array}$ & $\begin{array}{l}2.85 \\
\text { (Sering) }\end{array}$ & $\begin{array}{l}2.92 \\
\text { (Sering) }\end{array}$ & $\begin{array}{l}1.76 \\
\text { (Jarang) }\end{array}$ \\
\hline
\end{tabular}

\section{SIMPULAN}

Berdasarkan hasil penelitian yang dilakukandapat disimpulkan bahwa: (1) Didapatkan 4 kelompok kecanduan game online yaitu cluster yang tingkat kecanduan parah sebanyak 12 data dengan nilai rata-rata keseluruhan sebesar 3,04, lalu cluster yang tingkat kecanduan sedang sebanyak 21 data dengan nilai rata-rata keseluruhan sebesar 2,37, sedangkan clusteryang tingkat waspada kecanduan game onlinesebanyak 20 data dengan nilai rata-rata keseluruhan sebesar 2,18 dan cluster yang tidak kecanduan Game 
onlinesebanyak 17 data dengan nilai rata-rata keseluruhan sebesar1,75. Sedangkan faktor yang paling mendapatkan nilai tertinggi terdapat pada faktor Relapse (kecenderungan untuk bermain game online kembali setelah lama tidak bermain) dengan nilai rata-rata keseluruhan sebesar 2,54 dan nilai tertinggi di Cluster 2 adalah 3,33 (Jarang) di pertanyaan "Saya bertekad untuk berhenti bermain game online."; dan (2) berdasarkan nilai korelasi menggunakan Correlation matrix yanglebih dari 0,5 yaitu sebesar -0.885 dari penelitian yang telah dilakukan, maka dapat disimpulkan bahwa adanya korelasi antara tingkat kecanduan game online terhadap prestasi akademik mahasiswa di Universitas Ibn Khaldun Bogor.

Berdasarkan penelitian yang telah dilakukan maka peneliti mencoba memberikan beberapa saran untuk penelitian selanjutnya, yaitu: (1) pada penelitian selanjutnya, dalam pengambilan sampel data kuesioner sebaiknya diperbanyak dibagian data demografi responden (lebih detil) agar dapat memperoleh gambaran yang lebih komprehensif mengenai kecanduan game online dan hubungannya dengan prestasi akademik mahasiswa seperti : lokasi tempat tinggal, berapa pendapatan orang tua dalam sebulan, masalah psikologis seperti broken home, broken heart dan lain-lain. Untuk penelitian selanjutnya dapat mengolah data terhadap Indeks Prestasi persemester bukan hanya IPK (Indeks Prestasi Kumulatif).

\section{DAFTAR PUSTAKA}

Hastuti, N.F. 2013. Pemanfaatan metode $k$ means clustering dalam penentuan penerima beasiswa, Surakarta.

Kristanto, N.H., A. C. L.A \& H. B. S. 2016. "Implemantasi K-Means Clustering untuk Pengelompokan Analisis Rasio Profitabilitas dalam Working Capital," JUISI, vol. 02, no. 1, Februari 2016.
Lemmens, J.S., Valkenburg, P. M. \& Peter, J. 2009. Development and Validation of a Game Addiction Scale. Media Psychology, pp. 77-95.

Nugroho, C. A., Hendrawan, R. A. \& I. Hafidz. 2012. Clustering kelompok swadaya masyarakat (KSM) dalam menentukan kebijakan bantuan badan pemberdayaan masyrakat di kota Surabaya dengan menggunakan metode self-organizing map (SOM) dan KMEANS," JURNAL TEKNIK POMITS, pp. 1-6, 2012.

Pratiwi, P.C., Andayani, T.R., \& Karyanta, N.A. 2012. Perilaku Adiksi Gameonline Ditinjau dari Efikasi Diri Akademik dan Keterampilan Sosial pada Remaja di Surakarta. Jurnal Ilmiah Psikologi Candrajiwa, vol. 1, p. 1

Ridwan, M., Suryono, H., \& Sarosa, M. 2013. Penerapan Data Mining Untuk Evaluasi Kinerja Akademik Mahasiswa Menggunakan Algoritma Naive Bayes Classifier. Jurnal EECCIS, vol. Vol 7, no. 1, Juni 2013.

Singh, A., Yadav, A. \& Rana, A. 2013. Kmeans with Three different Distance Metrics. International Journal of Computer Applications (0975 - 8887), vol. 67, no. 10, April 2013.

Weinstein, A.M. 2010. "Computer \& Video Game Addiction-A Comparison between Game Users and Non-Game Users. The American Journal of Drug and Alcohol Abuse, vol. 36, p. 268-276 